\title{
Vyākaraṇic Texts and Śāstric Discourse ${ }^{1}$
}

\author{
Émilie Aussant
}

CNRS, Laboratoire d'Histoire des Théories Linguistiques

Univ. Paris Diderot, Sorbonne Paris Cité, France

\section{Introduction}

The history of humanity is full of evidence to show that speaking has always been a highly codified practice, all around the world. This is particularly true for Ancient India, at least for Brahmanical (ancient Hindu) India: the most ancient texts which have come down to us clearly indicate that Sanskrit, the "sacred, eternal and perfect" language, was the subject of very intense thought. ${ }^{2}$

In a previous article ("Les vidhi-sūtra de la grammaire de Pānini”), I dealt with the form and function of the Pāninian grammatical rules as well as with the question of their prescriptive character. Here, I would like to focus on another manifestation of the sasastric discourse in grammatical texts: through a careful study of the use of words such as dharma, śāstra and $s \bar{a} d h u$ - as well as their negative counterparts -, I will consider how these texts "declare themselves saāstric, justify their existence or even their indispensability, or otherwise reflect on their divine origin or their regulatory purpose". ${ }^{3}$ To do so, I will first give a brief overview of what śāstras and śāstric discourse are, then I will succinctly explain why Vyākarana (the classical Indian Sanskrit grammar) may be considered as the epitome of normativity and, finally, I will describe some of the manifestations of the śāstric discourse in three grammatical Sanskrit texts (Mahābhāṣya, Pradīpa, Uddyota).

\section{1 Śāstra and Śāstric Discourse - An Overview}

The term śāstra (derived from the verbal root śās- "to teach, instruct"), ${ }^{4}$ is commonly translated into English as "order, command, rule, precept". It refers to texts dealing with technical knowledge, being of recognized authority or commenting on an authoritative text. One must note that these śāstric texts were composed by members of the Brahmanical priestly and intellectual elite - the brahmins -5 that is to say by persons who, unlike others, have the right of access to the Sanskrit Vedic texts and of participation in Vedic ritual practices. They are, therefore, closely connected to the sphere of Brahmanical sacred textual knowledge. For whom and for what did they compose these texts? Very likely for themselves and the younger

1 I wish to thank Hugo David as well as Christel Fricke for their valuable suggestions.

2 The systematic description of the Sanskrit language made by Pānini about the $5^{\text {th }}$ or the $4^{\text {th }} \mathrm{c}$. BCE became, during the following centuries, the unquestionable instrument and model of a thorough codification of the language. But the acute consciousness of the norms of language very likely predated Pānini.

3 Leela Prasad, "Text, Tradition, and Imagination: Evoking the Normative in Everyday Hindu Life," Numen Vol. 53 (2006), No. 1, 1-47, p. 7.

4 Sheldon Pollock recalls Candrakīrti's (a Buddhist philosopher) analysis of the term: "śāstra is so called because it 'chastises' [śās] all one's inimical impurities and 'saves' [tra] one from evil rebirth." Pollock, "The idea of Śāstra in traditional India", in A. L. Dallapiccola (ed.), Shastric Traditions in Indian Arts, Vol. I “Texts" (Stuttgart: Steiner Verlag Wiesbaden GMBH, 1989), 17-26, p. 17.

5 During the immediate post-Vedic period, at least. Candrakīrti, quoted in the previous footnote, is a counterexample of a scholar who adopts the language of the śastra and who is not a member of the Brahmanical priestly and intellectual elite. 
generations of brahmins, in order to preserve their tradition. But by demonstrating, through the composition of their texts, that they were in possession of a very ancient and huge body of knowledge (a knowledge they did not intend to share with non-brahmanical communities, i.e. members of other castes as well as religious heterodox people such as Buddhists, etc.), they also legitimated themselves and their practices as well as their religious, political and social power.

Traditionally, the Vedas - the holy books which are the foundation of the Vedic religion, the ancient form of the Hindu religion - are conceived as the śästra par excellence. With the exception of poetry, economy and erotology, these texts represent the starting point of the sāstric literature on the requirements of the religious practice (even if, in the course of time, the branches of technical knowledge were emancipated from the priestly disciplines and developed by themselves).

The traditional Indian listings give between fourteen and eighteen "erudite" or "technical" branches of knowledge. Most of these texts are didactic textbooks consisting of collections of aphorisms (sütra): they regulate all kinds of human practices and they provide a model for these practices, as well as a justification. ${ }^{6}$ Whereas such cultural codes exist in every society, the ancient Indian culture is characterized by the fact that secular life as a whole was encoded in those 'cultural grammars', as Pollock calls them, ${ }^{7}$ at a relatively early date (around the beginning of the Christian era). The number of these texts, the wide range of disciplines they cover and the form they have taken - which I will deal with below - make the ancient Indian culture singular.

As Pollock already pointed out, the first occurrence of the word śāstra as meaning "rule" is found in grammatical - or Vyākaranic - texts. ${ }^{8}$ The early grammarians Kātyāyana $\left(3^{\text {rd }} \mathrm{c}\right.$. $\mathrm{BCE})$ and Patañjali $\left(2^{\text {nd }} \mathrm{c}\right.$. BCE) indeed state at length the regulations given by śăstras, not only as regards language but also as regards human agency in general, ${ }^{9}$ for the achievement of goals which I will come back to later. Later on, writes Pollock, "The great $7^{\text {th }}$ century Mīmāmssaka, ${ }^{10}$ Kumārilabhaț̣a, defines [śāstra] thus: 'śāstra is that which teaches people what they should and should not do. It does this by means of eternal words or those made by men." "Pollock will add that "[...] śästra was [then] thought of generally as a verbal codification of rules, whether of divine or human provenance, for the positive and negative regulation of particular practices." 12

As for the textual and extra-textual features of śāstras, one may mention the following three:

1. The most characteristic feature of these collections of rules which govern all kinds of processes is the degree of authority which they are invested with. This authority firstly comes from the fact that the śasstras are traditionally grounded in the Vedas, the epitome of

6 Another source which furnishes the norm is the conduct of the sisțtas, the "wise men". See Prasad, op. cit., pp. 11-12, and my "Sanskrit Grammarians and the 'Speaking Subjectivity'," Beiträge zur Geschichte der Sprachwissenschaft, Vol. 23 (2013), No. 1, 1-20.

7 Pollock, "Playing by the rules: Śāstra and Sanskrit literature," in A. L. Dallapiccola (ed.), Shastric Traditions in Indian Arts, Vol. I "Texts", op. cit., 301-312, p. 310.

8 Pollock, "The idea of Śāstra in traditional India," op. cit.

9 For instance, see in $\$ 3.2$ the last quoted passage of the Mahäbhāsya.

10 The Mìmāms à discipline constitutes an hermeneutics of ritual texts. Together with grammar (Vyākarana) and logic $(N y \bar{a} y a)$, it constitutes the master part of an Indian traditional scholar's training.

11 Ibid., pp. 17-18.

12 Ibid., p. 18. Prasad observes that, today, "śästra is one concept among others such as paddhati (custom), $\bar{a} c \bar{r} r a$ (proper conduct), sampradāya (tradition) and niyama (principle, restraint) that individuals employ to indicate moral authority and enactment.” Op. cit., p. 1. 
transcendent texts; as a consequence, śāstras often claim a transcendent or a divine origin for themselves or for the knowledge they convey. Their authority comes secondly from the fact that they indirectly give rise to the knowledge of what Hindus call the dharma. This very complex notion denotes, in a very general way, everything which leads to the good. Gonda defines dharma as follows: ${ }^{13}$

[...] in general [dharma] means the lawfulness and regularity, the harmony, the fundamental equilibrium, the norm which reigns in the cosmos, nature, society, and individual existence. Dharma is the basis for the norms of individual conduct, it sustains the structure of the community and regulates the continuity in all the manifestations of reality.

In the course of time, dharma will end by denoting the norm, its various manifestations and the means of achieving it. I will come back to this notion in $\$ 3.2$.

2. Many of the śāstras are composed in the sütra genre; they are didactic textbooks setting out, in a very economical and systematic way, the dogmas of a discipline which are to be learnt by heart and recited. They represent therefore guides that lay down the principles to be followed in order to carry out the diverse actions linked to the Vedic literature, such as the making of a sacrifice, ${ }^{14}$ the derivation of a word, the composition of a verse, etc. As a consequence, though descriptive in form, śästras expound things in a prescriptive way. ${ }^{15}$ As Louis Renou already wrote in his paper "Sur le genre du sütra dans la littérature sanskrite", in Indian Antiquity, "description signifie norme, ce qui est est ce qui doit être.""

Another feature, which results directly from the authoritative character of śāstras as well as from the composition in the sütra genre, is the systematicity of and, somehow, the repetition in these texts. The śāstric literature mainly consists of commentaries which endlessly go back over what has been taught in the founding - and most authoritative - text they gloss (whether or not in order to reassert it). In other words, it is a literature of accretion.

3. Though their subject matter is sacred, some of these texts - grammar and prosody most noticeably, according to Pollock ${ }^{17}$ - include a considerable amount of worldly (i.e. non sacred) data and allow the generation of additional secular material. Encoding, even for daily life, one way of acting or practising among several other possibilities, reinforces the normative status of śāstras.

\section{Vyākarana as an Epitome of Normativity}

The earliest śâstric works which are characterized by the features listed previously are the Vedāngas, the "limbs" of the Vedas. The Vedàngas consist of six ancillary disciplines; four of them - phonetics (śikșā), metrics (chandas), etymology (nirukta) and grammar (vyākarana) were developed to preserve the Vedic texts and two of them - astronomy (jyotișa) and sacrificial liturgy (kalpa) - to ensure the correctness of ritual's material procedure.

13 Quoted in Wilhelm Halbfass, India and Europe. An Essay in Understanding (Albany, NY: State University of New York Press, 1988), p. 312.

14 On this point, Jan Gonda, The Ritual Sūtras. Veda and Upanishads Vol. 1, fasc. 2 (Wiesbaden: Otto Harrassowitz, 1977), p. 489, observes: "The śrautasūtras are manuals compiled for a practical purpose, viz. giving directions to those who officiated at the several solemn sacrificial rites that were performed or recommended in Vedic times" (italics are mine).

15 See my "Les vidhi-sūtra de la grammaire de Pāṇini," forthcoming in Verbum.

16 Louis Renou, "Sur le genre du sütra dans la littérature sanskrite," Journal Asiatique, Vol. 251 (1962), No. 2, 165-216, p. 183.

17 Pollock, op. cit., p. 19. 
The most ancient grammatical work to come down to us is the Asțādhyāyz ("[Treatise] in eight chapters") - hereafter A - of Pānini, which would have been composed about the $5^{\text {th }}$ or the $4^{\text {th }}$ c. BCE. ${ }^{18}$ This work, which consists of nearly four thousand Sanskrit sūtras, describes a form of early Indo-Aryan language - later named Sanskrit - by means of a derivational system. The A is the founder text of the main Sanskrit grammatical school: the Panninian treatise gave rise to a rich literature of commentaries which goes from the $3^{\text {rd }} \mathrm{c}$. BCE to the $18^{\text {th }} \mathrm{c}$.

Now, why can Vyākarana, the classical Indian Sanskrit grammar, be said to be the "epitome of normativity"? As previously mentioned, linguistic activity has always been a highly codified practice. Due to the high-culture tradition associated with Vedic learning, the regulation of language - together with the regulation of ritual - was probably the first to be textualized and then quickly became a model for the regulation of other areas of human activity. One has to keep in mind that the first occurrence of the word śästra as meaning "rule" is found in the Mahābhāṣya - hereafter M - of Patañjali (Pollock 1989a: 17), a famous vyākaranic text (see $\S 3$ for more details). It is also in the vārttika - hereafter V - of Kātyāyana and the Mahābhāṣa that one finds the first reference to the Dharmasūtras (Olivelle 2004: 506, 2012). ${ }^{19}$

The other explanation of the role of Vyākarana as a model for regulation is linked to the way according to which the object of the discipline, that is to say, the Sanskrit language, was conceived. On this point, Wilhelm Halbfass (1988: 320, see also note 49 p. 551) writes, in a very illuminating way:

In general, there are important connections between the orthodox Hindu conceptions of language and dharma. Sanskrit is the language par excellence, of prototypical correctness, firmly established by its grammar and the linguistic usages of authoritative speakers, a domain of 'normative empiricism', an exemplary structure of rules and exceptions, complex and indefinitely differenciated, yet irreducibly one and unique. All this provides a most significant model and analogue for the 'orthodox' understanding of dharma.

\section{Manifestations of the Śāstric Discourse in the Mahābhāṣya, the Prad̄̄pa, and the Uddyota}

To begin with, a few words concerning the corpus studied here. The earliest extensive discussion of Pānini's sütras which has been preserved are contained in the värttikas of Kātyāyana ( $3^{\text {rd }}$ c. BCE), which themselves are known as cited and discussed in Patañjali's Mahābhāsya $\left(2^{\text {nd }}\right.$ c. BCE). The latter, traditionally considered as the major commentary on the Pāninian treatise ${ }^{20}$ sets out most of the topics which were dealt with during the following twenty centuries. Together with the vārttikas of Kātyāyana it quotes literally, it constitutes the first text of our corpus. The second text is the Pradipa of Kaiyata $\left(11^{\text {th }} \mathrm{c} ., \mathrm{P}\right.$ hereafter $)$, the most ancient complete commentary on the Mahäbhāsya, and the third text is the Uddyota of Nāgeśa $\left(17^{\text {th }}-18^{\text {th }}\right.$ c., U hereafter), a famous commentary on the Pradīpa of Kaiyața. Mention

18 See George Cardona, "Pāninini’s dates and the evidence of coinage", Pt. Ranganath Ramchandra Deshpande Memorial Volume, forthcoming.

19 dharmaśāstram ca tathā // (V 39 ad A 1.2.64, see M, I: 242). The Dharmaśāstra is mentioned there to illustrate the idea according to which the word denotes a generic entity: "one must not kill a brāhman" means "one must not kill any brāhman". This is the generic character of laws' formulation which is highlighted here.

20 Patañjali directly comments on 468 sütras of the A. 
should be made at this point of Bhartrihari $\left(5^{\text {th }}\right.$ c.): Kaiyața and Nāgeśa come after him and show (like any grammarian born after him) a great familiarity with his works. Bhartrhari played a major role in what Indologists call the "philosophy of grammar": he was a grammarian-philosopher who abundantly contributed to the search for knowledge that leads to liberation (moksa); he was the first to formalize the ideas regarding the role of grammar in the achievement of liberation. ${ }^{21}$ A lot of studies deal with this topic, so I will not dwell on it (see, among the most recent studies, Houben 2012 and Chaturvedi 2009).

The section of the Mahābhāṣya which contains many features of sāstric discourse is the introduction - Paspaśa . There, the following topics are discussed: $^{22}$

- the nature of words (what are the words taught in grammar? What is a word, generally speaking?)

- the aims of grammar (18 listed aims, mentioned through statements or stanzas)

- the method of teaching words

- the object (or referent) of words

- the question whether words are nitya "permanently there" or kärya "to be produced"

- the assumptions of grammar (grammar provides a restriction for the sake of dharma)

- the aprayukta, namely "non-used" words

- the topic of knowledge versus use (does dharma result from grammatical knowledge or from the use of correct words?)

- the meaning of vyākarana

- the teaching of speech-sounds in the so-called Pratyāhārasūtras

Among these ten topics or sections, three especially include passages which are of interest to us: the aims of grammar (see $\$ 3.1$ and §3.2), the assumptions of grammar (see $\S 3.2$ ) and the topic of knowledge versus use (see \$3.2). It is here, indeed, that one finds the first previously mentioned feature of the śāstric discourse, that is, the claim of a special link to transcendence and to dharma. Let us see how this manifests itself in the selected texts.

\subsection{Grammar and Transcendence}

Several passages present the grammarian (or, at least, the person who knows the grammar) as someone being in communion with an eternal form of speech, originating in a transcendent source. The first one constitutes the $12^{\text {th }}$ aim of the study of grammar:

[Vedic stanza:] He has four horns, three feet, two heads, seven hands. Bound in three ways, the bull loudly bellows. A mighty god has entered mortals. [Commentary:] The four horns are the four classes of words: noun, verb, preverb and particle. His three feet are the three tenses: past, future and present. The two heads are the two natures of words: permanent and to be produced. His seven hands are the seven case endings. "Bound in three ways" [means] bound in three places of articulation: chest, throat,

21 See, for instance, the kārikā 1.14 of the Vākyapadīya (VP hereafter): tad dvāram apavargasya vāimmalānām cikitsitam / pavitram sarvavidyānām adhividyam prakāsate // "[Grammar] is the door to liberation, the remedy for speech's impurities, the purification for all the sciences. It shines in each of these sciences."

22 See Joshi and Roodbergen (1986: iv-xxiv, see Primary references). 
head. "Mighty god" [means] speech (śabdah). So that we should have similarity with the mighty god, grammar must be studied. ${ }^{23}$

Nāgeśa explains the passage as follows:

The intention of the stanza is: the speech taught by the grammar (śabdaśastra ${ }^{\circ}$ ), in the shape of a bull, bellows; the mighty god, that is to say, speech in the shape of the internal guide, has entered mortals, that is, manifests its identity to them. In other words, because grammar makes the mighty god, the speech-brahman, known, the one who knows grammar becomes as though entered by him. ${ }^{24}$

In other words, the one who knows grammar becomes similar to a mighty bellowing bull-god, who is identified with speech. Immediately after this passage, Patañjali quotes a second Vedic stanza dealing again with a division of speech:

[Commentary:] Someone else says: [Vedic stanza:] "Speech has been measured in four feet; brahmins who have control over their mind know them. Three [of them], deposited in a secret place, do not stir; men speak the fourth part." 25

Traditionally, it is said that there are two ways of understanding this: 1) speech is divided into four classes of words (noun, verb, preverb and particle) and 2) there are four varieties of speech. According to the first interpretation, brahmins know all the words of the four classes and ordinary men know only one-quarter of each class of words. According to the second interpretation, brahmins know the four varieties of speech and ordinary men know only one variety. Let us see how Nāgeśa explains this superiority of brahmins:

In the bhāsya, manasa iṣinah: [Brahmins] who become master [over their mind] through the purification procedure of the mind or by doing violence to [their mind], diverting it from other objects. And these are the grammarians. [...] The idea is: the grammarian, through the strength of grammar $\left(\dot{s} \bar{a} s t r a^{\circ}\right)$ and through the yoga obtained by this strength, breaks the darkness of this secret place and knows everything. ${ }^{26}$

The grammar helps in gaining knowledge of every word; this knowledge, considered as a strength, helps the cessation of mental activities and this yoga helps in gaining knowledge of

23 catvāri śrnigā trayo asya pādā dve śìrșe sapta hastāso asya /

tridhā baddho vrșabho roravīti maho devo martyām à viśeșa // (Vedic stanza)

catvāri śrñgāṇi catvāri padajātāni nāmākhyātopasarganipātāśs cal trayo asya pādās trayah kālā bhūtabhavișyadvartamānāh / dve śīrșe dvau śabdātmānau nityah kāryaś ca / sapta hastāso asya sapta vibhaktayah / tridhā baddhas triṣu sthāneșu baddha urasi kaṇthe śirasīti / [...] mahān devah śabdah / mahatā devena nạ sāmyam yathā syād ity adhyeyam vyākaraṇam // (M, I: 3) vrṣabhākārah śabdaśāstrapratipādyah śabdo roravīti mahān devo 'ntaryāmirūpah śabdo martyān ā viśeșa svābhedam āvișkrtavān iti mantratātparyam/ mahato devasya śabdabrahmaṇo vyākaranajñāpyatayā vyākaraṇajñas tadāvișta iva bhavatīti yāvat // (U, I: 31, 1st col.)

25 apara āha / catvāri vāk parimitā padāni tāni vidur brāhmaṇā ye manīṣinaḥ / guhā trīṇi nihitā neingayanti turīyam vāco manuṣyā vadanti // (Vedic stanza) (M, I: 3)

26 bhāṣye manasa ìșinah / cittaśuddhikrameṇa vaśīkarttāro viṣayāntarebhyo vyāvṛttyā himsakā vāa / te ca vaiyākaraṇāh / [...] / vaiyākaraṇas tu śāstrabalena tadbalalabdhayogena ca guhāndhakāram vidārya sarvạ̣ jānātīti bhāvah / (U, I: 32-33) 
the four varieties of speech. ${ }^{27}$ This topic of four varieties of speech, classified according to metaphysical criteria will reappear later, in the works of Bhartrihari.

The second passage, which deals with the communion of the grammarian with the divine form of speech, constitutes the $14^{\text {th }}$ aim of grammar's study given, here again, through the quotation of a Vedic stanza:

[Vedic stanza:] "Where the wise have shaped speech with their mind, purifying it like groats with a sieve; there, being communicant, they know communion. In their speech, the beautiful Lakșmī is settled." [Commentary:] [...] Who are these [wise]? The grammarians. $^{28}$

Once again, Nāgeśa provides us with a clear explanation:

Here is the idea [of the passage]. Those who know the correct (sādhuñ) [words] through the analysis in base and suffix according to the grammar (śāstratah), who meditate on the purpose of the grammar (śāstra ${ }^{\circ}$, who by their knowledge clear the speech [residing] in their mind from incorrect (asādhubhyah) words, these [brahmins], their mind purified by the use, predated by the knowledge of [the grammar], of correct $\left({ }^{\circ} s \bar{a} d h u^{\circ}\right)$ words, having the perception of the durgah märgah as identical to themselves, that is to say, having a representation free from any difference between the brahman and themselves, they obtain sakhyāni, the communions because, in their speech, eșām vāci, in the brahman called veda, this bhadrāa, Lakșmī, who is the brahman who lights everything, is adhi, intensely nihita , settled. ${ }^{29}$

The knowledge of grammar, being speech-purifying, purifies the mind of those who know the grammar and thus, it seems to predispose them to the communion with the divine form of speech. Nāgeśa ends his commentary by saying that grammar leads to deliverance (mokșa; for more details, see §3.2), which is, briefly put, the end of the cycle of rebirth, the end of suffering, the end of ignorance.

There is still another passage, within the section devoted to grammar's aims, which illustrates the special link between knowledge of grammar and transcendence. This passage tells us that because of his knowledge of grammar, the god Varuna is described as a truth-deity (satyadeva); the Mahābhāsya will conclude: to become a truth-deity, grammar must be studied. I will not dwell on this passage, I prefer to say a few words about another passage which describes grammatical activity as sacred. The context can be described as follows. The very first Pāninian sūtra teaches the technical name the phonemes $\bar{a}$ ai au bear within the grammatical treatise:

27 See Pierre-Sylvain Filliozat, tran., "Le Mahābhāṣya de Patañjali avec le Pradīpa de Kaiyaṭa et l'Uddyota de Nāgeśa. Adhyāya 1 Pāda 1 Āhnika 1-4” (Pondichéry, Institut Français d’Indologie, 1975), p. 57, n. 3.

28 śaktum iva titaünā punanto yatra dhīrā manasā vācam akrata / atrā sakhāyaḥ sakhyāni jānate bhadraișām lakșmīr nihitādhi vāci // (Vedic stanza) [...] / ke punas te / vaiyākaraṇāh / (M, I: 4)

29 ayam bhāvah / ye śāstratah prakrtipratyayavibhāgena sādhuñ jĩ̄ātvā śāstrārthadhyānavanto mānasam jūānena vācam asādhubhyaḥ prthak kṛtavantas te tajjñānapūrvakasādhuśabdaprayogair labdhāntaḥkaraṇaśuddhayo 'tra ya eșa durgo mārgo brahmarūpas tatrātmanā saha samānakhyātayas tyaktabhedabhāvanāh sakhyāni sāyujyāni prāpnuvatel yata eșạ̄n vāci vedākhye brahmaṇi yā bhadrā lakșmīh sarvabhāsakabrahmarūpā sā adhi adhikam nihitā bhavati / (U, I: 35, 2nd col.) 
[The phonemes] $\bar{a}, a i, a u$ [bear the technical name] $v r d d h i .^{30}$

As it is the first rule of the grammar, it is the occasion for the commentators to discuss various topics. One of them is the identification of the technical term (samjiña) and of its bearer (samjnin): the sütra, indeed, is limited to both terms and both terms are in the nominative case. A suggestion is made to suppress the ambiguity of the rule, otherwise, says the Mahāhassya, incomprehension might arise, as in the meaningless sentences of the current usage:

[Things] do not go in grammar as in current usage. The master (i.e. Pāninini), who possesses authority ( $\operatorname{pramann}^{\circ}$ ), a blade of purifying darbha grass in his hand, seated in a pure place, facing the East, composed, with a great effort, the sütra; in these conditions, it is impossible even for a single phoneme not to have a meaning and even more so for such a long sütra. ${ }^{31}$

To establish its authority, there is no better way than to make grammar a sacred activity.

\subsection{Grammar and dharma}

The concept of dharma occupies the central position in India's intellectual history, "irrespective of linguistic, sectarian, or regional differences". ${ }^{32}$ The term is derived from the verbal root $d h r$ - "to hold", "to support". ${ }^{33}$ On the ethical-social level, dharma refers to a general law - as well as to its various manifestations - to which human beings must conform (from the very early occurrences of the term, obligation is implied). ${ }^{34}$ This concerns the natural order of things (or "natural law") - acts such as eating and sleeping must be accomplished to preserve life and health - just as much as the "ethical law", that is to say social and religious duties which must be accomplished and reproduced to maintain good order. Within the framework of the three aims of human life (purușārtha) theme, ${ }^{35}$ dharma represents everything that is good on the moral level; the two other aims being artha (everything which is useful on the social level) and kamma (everything which is pleasant on the sensorial level) - note that, traditionally, a fourth aim is added, which is superior to the three others: mokșa "deliverance".

As already "pointed out by Ashok Aklujkar, within the grammatical context, the word dharma "[...] must mean some kind of positive effect created by the user of the language with which $\mathrm{P}[$ atañjali] and $\mathrm{BH}$ [artṛhari] were concerned [...]. [...] dharma is spoken of as directly

30 verddhir ādaic // (A 1.1.1)

31 na yathā loke tathā vyākaraṇe/ pramānabhūta ācāryo darbhapavitrapāṇih̆ śucāv avakāśe prānmukha upaviśya mahatā yatnena sūtram praṇayati sma tatrāśakyạ̣ varṇenāpy anarthakena bhavitum kị̣ punar iyatā sūtreṇa / (M, I: 39)

32 Patrick Olivelle, "Preface," in Olivelle (ed.), Dharma, op. cit., pp. vii-viii.

33 Dhárman (neuter) originally means "hold", "support" and dharmán (masculine) originally means "supporter" cf. Paul Horsch, "From creation myth to world law: the early history of dharma," in P. Olivelle (ed.), Dharma, op. cit., 2-26, p. 2. Horsch adds: "Although the verb is found in other Indo-Germanic languages, they lack the exact equivalent of the substantive, so that the concept possesses a specific Indian character from the very beginning," ibid.

34 See ibid., pp. 8, 10.

35 This theme seems to be mentioned for the first time in the Mahābhāṣya (on V 9 ad A 2.2.34), even if only to illustrate a linguistic phenomenon. It will constantly reappear after that and will be copiously elaborated in various texts. For more details on this topic, see Charles Malamoud, "Sémantique et rhétorique dans la hiérarchie hindoue des 'buts de l'homme'," in his Cuire le monde. Rite et pensée dans l'Inde ancienne (Paris: Éditions La Découverte, 1989). 
leading to some kind of elevation and, indirectly, to attainment of brahman or spiritual liberation (mokșa). ${ }^{36}$ Later on, he adds (2009: 297):

Ultimately, what the grammarians claim is not that one gains dharma through grammatical usage simply because the usage is grammatical - because one succeeds in imitating someone whose usage happens to be deemed correct, faithful to the autorities or respectable. The usage must be backed or precedeed by a knowledge of the śāstra behind it. This requires special effort, staying away from at least some of the pleasures that attract common men. In other words, it presupposes restraint of the senses and concentration of the mind to the extent one is capable of such things. Acceptance of a similar mode of living [...] is elsewhere said in ancient Indian literature to make one a better person. ${ }^{37}$

Let us look at various passages illustrating the ideas expressed by Ashok Aklujkar.

Among the 18 aims of the study of grammar, the first three, described as "principal" (mukhya) by Patañjali, ${ }^{38}$ establish (at least for the commentators, Kaiyaṭa and Nāgeśa) a very clear link between grammar and dharma.

The section devoted to the aims of the study of grammar starts as follows:

But what are the aims of the instruction of words? ${ }^{39}$

Kaiyața comments on this preliminary question as follows:

käni punar-iti - The question is whether the study of grammar is like an obligatory act [nityam karma], like the worship [of the sun] at the sandhya $\bar{a}^{40}$ etc., or an optional one $[$ kāmyam $] .^{41}$

36 Ashok Aklujkar, "Can the grammarians' dharma be a dharma for all?," in P. Olivelle (ed.), Dharma, op. cit., 265-310, p. 279.

37 Ibid. p. 297. Note that within the Aștâdhyāyā of Pānini (5th c. BCE), dharma is used five times, in particular in rules related to the formation of derivatives such as dhärmika "who observes or practises dharma" (according to A 4.4.41), dharmya "attainable by the dharma" (according to A 4.4.91) and dharmya "not deviating from dharma" (according to A 4.4.92). As already noticed by Olivelle, Pānini does not consider these derivatives as belonging to the Vedic register: according to him, these forms are used within the $b h \bar{a} s \bar{a}_{\text {, }}$ the ordinary or common linguistic variety of which Pānini was probably a speaker; see "The semantic History of Dharma," op. cit., p. 507. This presupposes that, by Pānini’s time, the notion of dharma no longer belonged to the Vedic sphere but to the mundane one. Still according to Olivelle, the texts composed during the middle and late Vedic periods (800-400 BCE) used dharma as a "[...] part of the specialized vocabulary associated with royalty, especially because of its frequent use within the royal consecration (rājasūya). In all likelihood, dharma referred to social order and the laws of society that the king was obligated to enforce" (ibid., p. 503). It is very likely that Pāninini had this meaning in mind while composing the Aștāahyāyī.

38 The reason given by Patañjali is that they concern the meaning of Vedic texts. The aims listed by him are described as "secondary".

39 kāni punaḥ śabdānuśāsanasya prayojanāni / (M, I: 1)

40 Sandhya denotes transitional moments: dawn and twilight.

41 kāni punar iti / kị̣ sandhyopāsanādivad vyākaraṇādhyayanam nityam karmātha kāmyam iti praśnah // (P, I: 16, 1st col.). Kaiyața, by asking this question, takes up again an issue dealt with by Bharțhari, in his Mahābhāṣya-dīpikā: śāstre ca yā pravṛttị adhyayanam prati sā saty arthitve / arthitvam ca satsu prayojaneșu / na cedam nitya-karmāvaśyam kartavyam / nitye karmaṇy apravrttāv adharmah / anityeșu kāmacāraḥ / yadi ca prayojanāni asya na bhavișyanti kutaḥ pravartișyata iti pṛcchati - kāni punar asya śabdānuśāsanasya prayojanāni / (MD: 5) "And the activity of studying in a [particular] śāstra [is there] when one desires that. And one desires [that] when benefits [are available]. But this [study of grammar] is not a nityakarman which must necessarily be undertaken. The non-undertaking of a nityakarman [results in] 
The comment immediately puts the issues into an exegetical perspective: ${ }^{42}$ what signifies the study of grammar in terms of ritual merit or unworthiness? Is it an obligatory act which brings no reward but whose non-performance is a cause of demerit. Or is it an optional act which brings visible benefits?

Nāgeśa reformulates this idea in the following terms:

[Kaiyata] says this: kim sandhyā. The idea is: the intention of the question [asked in the M] is: is the fruit of [grammar's] study, through the knowledge of words, to avoid the fault caused by the non-knowledge of [grammar]? Or is it something which comes in addition to [the avoidance of a fault] ${ }^{43}$

The answer, regarding the aims of grammar's study, is provided by Kātyāyana:

Preservation [of Vedic texts] (rakșa), [suitable] adaptation [of a Vedic linguistic form according to the ritual context] ( $\bar{u} h a)$, [complying with a] Vedic injunction (ägama), economy [in learning the correct linguistic forms] (laghu), removal of doubt (asamdehāh) are the aims of [grammar's study]. ${ }^{44}$

Patañjali then comments on each of these aims in turn. Concerning the first one, he says:

For the preservation of the Vedas, grammar should be studied. Because one who knows deletions, augments, sound-substitutions [etc.], will preserve the Vedas properly. ${ }^{45}$

Kaiyața comments the passage as follows:

By [the words] rakșa [etc.], he says that [the study of grammar] indirectly serves as a means of reaching the aims of human life (purușārtha $\left.{ }^{\circ}\right){ }^{46}$

And Nāgeśa adds:

demerit. [Whether or not] anitya [karmāni] are undertaken, depends on one's own sweet will. And if there will be no benefits connected with that [anityakarman], why should it be undertaken [at all]? With this in mind [the author] asks 'But what [etc.]'.” (Translation by Joshi and Roodbergen, p. 26. See references).

That is to say, in a "mìmāmsaka" perspective (on Mìmāmsāa, see footnote 8). Grammar (Vyākarana) and exegesis $(M \bar{i} m \bar{a} m s \bar{a})$ frequently influenced each other, either on the level of the form or of the substance. Bhatțoji Dỉkșita, a strongly orthodox grammarian of the 17th century, often resorted to the exegetical style of argumentation, in particular to establish the degree of authoritativeness of various sources (see Jan E.M. Houben, "Pāninian grammar of living Sanskrit: features and principles of the Prakriyā-Sarvasva of Nārāyaṇa-Bhațta of Melputtūr," forthcoming in Proceedings of the Workshop "The Indian Traditions of Language Studies”, ICHoLS XI, Potsdam 2008, §1.2).

43 tadāha kim sandhyeti / śabdajñānadvārādhyayanasya tadajñānaprāptapratyavāya-parihārah phalam uta tadatiriktam api kim cid iti praśnāśaya ity arthah / (U, I: 16, 2nd col.). Answers to this question will be given later, when the topic reappears with Patañjali explaining the 3th aim of the study of grammar ("[complying with a] Vedic injunction"). According to Kaiyata (P, I: 19, 2nd col.), the study of grammar is an obligatory act; according to Nāgeśa (U, I: 19, 2nd col.), it is both an obligatory and an optional act. rakṣohāgamalaghvasamdehāh prayojanam // (V 2, I: 6)

45 rakṣārtham vedānām adhyeyam vyākaranam / lopāgamavarṇavikārajño hi samyag vedān paripālayiṣyati // (M, I: 1)

46 pāramparyena purușārthasādhanatām asyāha - rakșeti / (P, I: 17, 1st col.) 
The aim of human life [consist here in] dharma and deliverance. ${ }^{47}$

Once again, commentators give an exegetical tone to the passage they comment on. The idea which seems to be mentioned here is the following: the instrument for the achievement of dharma (and deliverance) is the knowledge of the Vedas. By preserving and enabling the proper understanding of Vedic texts, that is to say, by enabling the knowledge of Vedic words (their formation and then their primary meaning), the grammar constitutes an indirect means of reaching the aims of human life.

There follows a series of passages dealing with the importance of knowing and/or using correct words (sādhu śabda), that is to say, words taught in grammar. These passages mainly concern the sacrificial context: there, a single mispronunciation can lead to the worst punishment. Several illustrations are given, like the death of the god Vṛtra, killed by Indra because of a stress misuse.

Below I quote two passages of the Mahābhāsya (together with their commentary by Nāgeśa). Both, as Aklujkar already observed, make "dharma a concern of the grammarian through the notion of grammaticality". 48 The first one, which takes place in the section devoted to the assumptions of the grammar (see the outline given in $\S 3$ ), deals with the idea according to which dharma results from the use of correct words. The second one, which takes place in the section devoted to the topic of knowledge versus use, deals with the idea (which is also the conclusion of Patañjali) according to which dharma results from the knowledge of correct words.

Let us consider the first passage. While discussing the role played by current usage in language learning, a question is raised:

Then, if current usage is authoritative regarding these [words, their meaning and their relationship], what is the purpose of grammar? When [it is assumed that the use of words is occasioned by the thing-meant, on account of] the current usage, grammar provides a restriction [on the use of words for the sake of] dharma. ${ }^{49}$

Dharma, then, results from the use of correct words (that is, words the formation of which is taught in grammar). Nāgeśa comments on this point as follows:

The intention is: [...] grammar makes a restriction: only go ("bull"), etc., when they are used with the knowledge of their analysis 'this is its basis, this is its suffix', generate dharma, not gā vi (corrupt form of go), etc. ${ }^{50}$

The Mahābhāṣya goes on, commenting on a vārttika from Kātyāyana:

47 purușārtho dharmo mokșaś ca / (U, I: 17, 2nd col.). Nāgeśa mentions only these two aims of human life. This is probably a reference to the Vedāntic classification of purușārthas where kāma and artha are considered as belonging to the "pleasant" sphere (preyas), whereas dharma and mokșa are considered as belonging to the "righteous" sphere (śreyas).

48 Aklujkar, op. cit., p. 275.

49 yadi tarhi loka eșu pramāṇam kị̣ śāstreṇa kriyatel lokato 'rthaprayukte śabdaprayoge śāstreṇa dharmaniyamah / (M, I: 8)

50 [...] śāstreṇāsyeyam prakrtir iyam pratyaya ity ādiprakrtyādivibhāgajñānadvārāa gavādaya eva prayuktā dharmajanakāh, na gāvyādaya iti niyamaḥ kriyate iti tātparyam // (U, I: 56) 
(Värttika:) 'Like in [the case of restrictions made] in current usage and in the Vedas'. [...] In the current usage, to begin with, it is stated: 'a tame cock and a tame pig should not be eaten'. But what is called 'food' is taken for the appeasement of hunger. And it is possible to appease hunger by [eating] the meat of a dog, etc. With regard to this, a restriction is made: this may be eaten, that must not be eaten. In the Vedas as well, it is stated 'a brahmin observes the vow of living on milk, a kșatriya (a member of the second caste) of living on gruel, a vaiśya (a member of the third caste) of living on curd'. But what is called 'vow' is observed for the sake of taking food. And it is possible to observe a vow of living on rice and meat also. With regard to this, a restriction is made (i.e. the brahmins concerned are not supposed to live on anything other than milk). [...] In the same way, here too, when meaning can be understood from correct and incorrect words equally, a restriction is made for dharma, namely, that meaning is to be conveyed by correct words only, not by incorrect words; if done in this way, it leads to happiness. ${ }^{51}$

This passage is typical of sāstric literature: it puts, side by side, the everyday life context, the Vedic context, the grammatical or linguistic context as well as their regulation: in the three types of context, one selects a behavior among several possibilities and establishes it as the norm.

Now, let us consider the second passage, the one where Patañjali concludes that dharma is generated by the knowledge of correct words alone:

Or rather, let dharma [lie] again ${ }^{52}$ in the knowledge [of correct words] alone. - But it has been pointed out that if dharma [lies] in the knowledge [of correct words], it will be the case for adharma ${ }^{53}$ as well. - There is no such fault. [...] although adharma [lies] in the knowledge of corrupt words, still, through the dharma which [lies] in the knowledge [of correct] words, the fault will be removed and [the speaker] will be associated with greater bliss. As regards the objection made previously, namely 'a restriction [holds] relating to [ritual] practice', [we answer that] the restriction concerns sacrificial ritual. For one tells: 'there were two ancient sages, named yarvānas-tarvānas, who possessed a direct perception of dharma, who knew the far and the near, who knew what could be known and who had come to realize ultimate reality. These worthy [sages], when they should have said yad vā nas tad vā nas ('whatever [happens] to us, [let] that [happens] to us'), they said yarvānas tarvānas; but they did not use corrupt words at the time of a sacrificial ritual'. ${ }^{54}$

51 yathā laukikavaidikeșu // [...] loke tāvad abhakșyo grāmyakukkuțo 'bhakșyo grāmyaśūkara ity ucyate / bhakșyam ca nāma kṣutpratidhātārtham upādīyate / śakyam cānena śvamāmsādibhir api kṣutpratihantum / tatra niyamah kriyate idạ̣ bhakșyam idam abhaksyam iti / [...] vede khalv api payovrato brāhmaṇo yavāgūvrato rājanya āmikșāvrato vaiśya ity ucyate / vratam ca nāmābhyavahārārtham upādīyate / śakyạ̣ cānena śālimāmsāāiny api vratayitum / tatra niyamah kriyate / [...] evam ihāpi samānāyām arthagatau śabdena cāpaśabdena ca dharmaniyamah kriyate śabdenaivārtho 'bhidheyo nāpaśabdenety evam kriyamānam abhyudayakāri bhavatīti // (M, I: 8)

52 This argument was previously asserted and then refuted.

53 That is to say, "non-dharma", "relegious demerit" in this context.

54 athavā punar astu jñ̄ana eva dharma iti / nanu coktạn jūāne dharma iti cet tathādharma iti / naișa doṣah / [...] yady apy apaśabdajñāne 'dharmas tathāpi yas tv asau śabdajñāne dharmas tena sa ca doṣo nirghānișyate bhūyasā cābhyudayena yogo bhavișyati / yad apy ucyata ācāre niyama iti yājñe karmaṇi sa niyamaḥ / evam hi śrūyate / yarvāṇas tarvāṇo nāmarșayo babhūvuḥ pratyakșadharmānạh parāparajñā 
One notes that at the end of the passage, Patañjali, in a quasi instinctive manner, goes back to the thesis of the "use" of words. Underlying the distinction between "knowledge" and "use", there is the question of how to access to the dharma which is in play: to say that only the knowledge of correct words leads to dharma prevents non-elite or heterodox members of the society (who are not trained in grammar) to reach dharma through this means. But when concrete situations of language use are under discussion, religious considerations are sometimes relegated to the background. However that may be, the knowledge of correct words is closely linked to the use of correct words, and to move from one to the other is unavoidable, especially for a trained mind concerned with brahmanical interests.

Nāgeśa comments on the passage as follows:

[...] it is the knowledge [of correct words] alone which is the cause of [dharma], because the one who does not know grammar does not obtain dharma, even from a correct use [of words]. [...] In the bhāsya: abhyupayya eva - the idea is: because the knowledge of [correct] words goes together with the knowledge of corrupt words, when a fruit is going to be produced by the knowledge of [correct] words, the knowledge of corrupt words, which only goes along with [the knowledge of correct words], does not produce a separate fruit. [...] In the bhassya: anyatrāniyamah - By the use of correct words during the sacrificial ritual, there is dharma; by the use of corrupt words, there is adharma. In this context only (i.e. sacrificial ritual) the use of both [kinds of words] is restricted. But in other contexts, there is no restriction regarding the use of correct and corrupt words. ${ }^{55}$

The end of the passage (in the Mahābhāṣya and here, in Nāgeśa's gloss) is also interesting in so far as it implies that the use of correct words leads to dharma, as far as the ritual context is concerned. The linguistic variation would then be tolerated in non-ritual contexts. This presupposes a two-sided conception of grammaticality: a hard version (in play in ritual contexts) and a supple (in play in contexts other than ritual). But that topic goes beyond the scope of the paper.

\section{Conclusion}

Through his intellectual activity, which is described as highly sacred and purifying, the (brahmin-) expert in grammar is predisposed to communion with the divine form of speech, he becomes omniscient (i.e. knows things which are beyond the ordinary word) and gains a means of reaching dharma and deliverance, first because he preserves the Vedic texts (the only real instrument for the achievement of dharma) and second because he knows (and uses!) correct words only.

By continuously declaring - in the studied passages - its special link to transcendence and to dharma, grammar demonstrates the high degree of authority with which it is provided and which justifies its existence, its indispensability, its regulatory purpose and then, its śāstric status.

viditaveditavyā adhigatayāthātathyāh / te tatrabhavanto yad vā nas tad vā na iti prayoktavye yarvānas tarvāṇa iti prayuñjate yājñe punạ karmaṇi nāpabhāṣante / (M, I: 10-11)

55 [...] tathāpy avaiyākaraṇasya samyakprayogād api dharmābhāvena jūānam eva taddhetuh / prayogas tu tasya dvāram iti bhāvah // [...] bhāṣye - abhyupāya eveti / apaśabdajñānanāntarīyakam śabdajñānam iti śabdajñānena phale jananīye sahakāritaivāpaśabdajñānasya na prthakphalateti bhāvah / [...] bhāṣye anyatrāniyama iti / yajñe suśabdaprayogād dharmo 'paśabdaprayogād adharma iti tatraiva tayoh prayoganiyamaḥ / tadatiriktasthale tu suśabdāpaśabdayoḥ prayoge 'niyamaḥ / (U, I: 66-68) 
Grammatical texts perfectly illustrate the religious sāastras' genre. But in substance, with the exception of Bhartrhari's works, they do not contain anything new, they borrow and adapt debates which are carried out elsewhere.

\section{References and abbreviations}

\section{Abbreviations}

\begin{tabular}{|c|c|}
\hline A & Aștāadhyāȳi \\
\hline M & Mahābhāṣya \\
\hline MD & Mahābhāṣyadīpikā \\
\hline $\mathrm{P}$ & Pradīpa \\
\hline U & Uddyota \\
\hline V & Vārttika \\
\hline VP & Vākyapadīya \\
\hline
\end{tabular}

\section{Sanskrit texts}

Aștādhyāȳī of Pāṇini: Aștâdhyāy $\bar{\imath}$ of Pānini, Roman Transliteration and English Translation by Sumitra M. Katre, Delhi, Motilal Banarsidass, 1989.

Mahābhāṣya of Patañjali:

- a) The Vyākarana-Mahābhāșya of Patañjali, Edited by F. Kielhorn, Third Edition Revised and Furnished with Additional Readings, References and Select Critical Notes by K.V. Abhyankar, Poona: Bhandarkar Oriental Research Institute, 1962, 2 vol. ( $1^{\text {st }}$ Edition: 1880, $2^{\text {nd }}$ Edition: 1892).

- b) Patañjali’s Vyākaraṇa-Mahābhāṣya Paspaśāhnika. Introduction, Text, Translation and Notes by S.D. Joshi and J.A.F. Roodbergen, Pune, University of Poona, 1986.

Mahābhāṣyadīpikā of Bhartṛhari:

The Mahābhāṣya-Dīpikā of Bhartrhari. Critical Edition by K.V. Abhyankar and V.P. Limaye, Supplement to Annals of the Bhandarkar Oriental Research Institute 43, 1962.

Pradīpa of Kaiyața:

Patañjali's Vyākaraṇa Mahābhāṣyam with Kaiyața's Pradīpa and Nāgojibhatța's Uddyota. Notes by A.G. Shastri, Edited by Dr. Bal Shastri, Delhi, Pratibha Prakashan, 2001 [1938], 6 volumes.

Uddyota of Nāgeśa:

see Pradīpa of Kaiyața

Vākyapadīya of Bharț̣hari:

Bhartṛharis Väkyapadīya. Versuch einer vollständigen deutschen Übersetzung nach der kritischen Edition der Müla-Kärikās von Wilhelm Rau. Hrsg. von Oskar von Hinüber, Stuttgart, Franz Steiner Verlag, 2002.

Vārttika of Kātyāyana: see Mahābhāṣya of Patañjali (a). 